Никола Крчмар

Универзитет у Новом Саду

Филозофски факултет

Докторске студије Историје

Карловачка гимназија, Сремски

Карловци

nkrcmar84@gmail.com
ОРИГИНАЛНИ ИСТРАЖИВАЧКИ РАД

UDK 371.3::94

DOI: $10.19090 / \mathrm{mv} .2017 .8 .53-69$

\title{
УПОТРЕБА ФОТОГРАФИЈЕ У НАСТАВИ ИСТОРИЈЕ НА ТЕМУ ХОЛОКАУСТА
}

\begin{abstract}
АПСТРАКТ
У раду се разматрају најоптималнији избори облика рада и наставних метода који се могу користити у наставној јединици о холокаусту. Акценат је на научним, методичким, педагошким и психолошким компетенцијама наставника као основним предусловом за извођење ваљаног часа у настави историје. Рад ће понудити на који начин ликовни материјал историјског садржаја као очигледно средство у настави историје може да се примени са осталим наставним методама водећи рачуна да једна другу исправно допуњавају. Фотографија као материјал документарног карактера може да се користи у великом броју наставних јединица и то не само на часовима историје већ и у структури осталих наративних предмета где се значајно место даје селекцији материјала. Важан сегмент у настави који се овде уочава јесте и питање мотивације коју треба поспешити комбиновањем различитих наставних облика. У раду ће бити изложени најважнији методички принципи којих се наставник мора придржавати.
\end{abstract}

Кључне речи: фотографија, холокауст, настава историје, методика наставе историје, Други светски рат.

\section{THE USE OF PHOTOGRAPHS IN HISTORY LESSON ON THE TOPIC OF HOLOCAUST}

\begin{abstract}
The paper discusses the most optimal choices of forms and teaching methods that can be used in a lesson on Holocaust. The emphasis is on scientific, methodological, pedagogical and psychological competencies of the teacher as the basic prerequisites for proper realization of a history lesson. The paper presents a way of using historical art material as a visual aid in teaching history with other teaching methods while making sure that
\end{abstract}


they complement each other properly. Photograph as a documentary material can be used not only in history lessons, but also in the structure of other narrative subjects where notable space is given to the selection of materials. An important part of teaching that can be observed here is the question of motivation, which should be improved by combining different teaching forms. The paper includes the most important methodological principles, which the teacher must adhere to, and an annex containing lesson plan on the subject of Consequences of the war - Holocaust, genocide, and casualties.

Keywords: photograph, Holocaust, history teaching, teaching methods in history, World War II.

\section{1. УВОД}

У основи проблема свих хуманистичких наука које су по својој природи наративног карактера, посматрано из угла ученика, јесте читање које чини неизоставни метод у процесу савладавања материје. У овом случају дефиниција читања не подразумева механичко понављање већ смислено усвајање које се квантитативно не би смело ограничавати, стога ни читаоци не чине само књижевно естетску категорију већ социолошкоинтелектуалну. Два значајна фактора која могу довести до делимичног превазилажења овог проблема јесу подстицај мотивације и методичко педагошке способности професора. Постизањем мотивационог фактора ученицима се олакшава процес савладавања градива и омогућава интелектуална ширина која поспешује образовни систем у целини. „Мотивацију за учење као посебну врсту мотивације одређујемо као тенденцију ученика да академске активности доживе као смислене и вредне и-или као средство за долажење до академских добити (оцене, дипломе)” (Требјешанин 2009: 14). Да би квалитет и трајност наученог били већи потребно је радити на подстицају унутрашње мотивације која у односу на спољашњу нуди и применљивост знања у свакодневном животу. Овај други фактор - професор, заправо може да врши директан утицај на мотивацију ученика преко сопствене стручности, ауторитета и жеље за остваривањем постављеног циља. Када се ова два интерактивна фактора барем делимично превазиђу може доћи до појачане когниције која води ка читању школске и шире литературе што је у историји (као предмету и науци) најзначајнији вид сазнајног процеса. Важан моменат у квалитетном извођењу часа јесте примена различитих облика рада без обзира на врсту наставне јединице у 
оквиру једног часа која поспешује активацију а редукује пасивизацију ученика. У оквиру активног учешћа ученика у наставном процесу не може се очекивати само репродукција усвојеног и савладана хронологија, већ пре свега критичка анализа неког историјског феномена (догађаја, личности, појаве), те паралелно сагледавање већег броја историјских процеса и њихова рефлексија на каснија раздобља па чак и данашњи период. Свакако оваква очекивања не могу бити постављена на нивоу одељења већ морају бити у складу са стандардима постигнућа. Са тим у вези неопходно је поштовање индивидуалности (интелектуалне, социјалне, емоционалне..).

\section{2. ИЛУСТРАТИВНО-ДЕМОНСТРАТИВНЕ МЕТОДЕ У НАСТАВИ ИСТОРИЈЕ}

При обради било које наставне јединице неизоставна је употреба очигледности ради квалитетнијег преношења знања, од којих је унутрашња, она коју чини само излагање наставника уз евентуалну консултацију изворних текстова, значајнија јер суштински дотиче проблем о коме се расправља. Уз помоћ унутрашње очигледности наставник разлаже постављену проблематику, дефинише кључне појмове и повезујући са претходним градивом надовезује ново знање.

Тек када се оствари велики део постављених циљева може се прећи на спољну очигледност која мора имати једино функцију допуњавања, никако не може бити примарна или једина. ${ }^{1}$ Коришћење илустративнодемонстративних метода у настави историје није неопходно увек, нарочито при понављању градива, али је препоручљиво јер буди пажњу ученика и активира их на коментаре и врло често код визуелних типова такво знање остаје трајно усвојено. Активирање већег броја чула повећава вероватноћу памћења без обзира да ли се ради о градиву или сасвим баналном примеру из свакодневног живота. Спољашња очигледност у оквиру илустративне методе се може поделити у три велике групе:

1) Предметна очигледност у коју спадају сви материјални остаци из прошлости као што су посуђе, оруђе, накит, грађевине, локалитети који се могу видети на екскурзијама или у оквиру наставе уколико се у одређеном месту има шта посетити. Најбољи пример очигледне наставе јесу музеји са којима наставници историје морају сарађивати и у свом годишњем плану

\footnotetext{
${ }^{1}$ О овоме детаљније видети Перовић (1995: 97-106).
} 
предвидети минимум једну посету у зависности колико је школа удаљена од најближег објекта овог карактера. На том месту је чак могуће и реализовање наставне јединице уз асистенцију или без кустоса. Понекад наставници несвесно преносе субјективан став о некој историјској појави која се управо у музејима може осетити, боље упознати. У раду о релацији историје и музеологије Живко Секулић управо наводи да је реч „о трајним и веома значајним дифузорима знања и културе, по узору на остале јавне институције са истим или сличним задацима нпр. архиви, библиотеке, галерије итд”. (Секулић 1998: 180-181).

2) Ликовна очигледност садржи елементе уметничког стваралаштва који могу потицати из периода који се обрађује али и из садашњости, при чему се мора водити рачуна да се тематски мора односити на тематику која се обрађује. Важно је нагласити да средства ликовне очигледности из садашњости могу имати значајну улогу у креативним активностима ученика. ${ }^{2}$ Ова врста демонстративне методе може се поделити на још две подврсте: а) ликовни материјал документарног карактера (о коме ће више речи бити у наредном поглављу) и б) ликовни материјал уметничког карактера (сва вајарска и сликарска дела која ближе и живописније описују неки историјски догађај или неку личност која се обрађује на часу).

Вајарске скулптуре се налазе на одређеним локалитетима (нпр. споменици жртвама рације из Другог светског рата) или у музејима. Уколико се ради о сликама избор извора је далеко већи и оне нам нуде живописније призоре на основу којих их можемо разврстати на: оне које нам приказују одређене догађаје (најчешће битке, револуције, крунисања...) где нам се нуди верно преношење важних тренутака ${ }^{3}$; потом друштвени профил свакодневног живота тзв. типолошке слике које су ретки материјални извори за стари век; оне које су најзаступљеније у извођењу наставе а то су портрети историјских личности и на крају карикатуре.

3) Очигледност помоћу средстава са условним знацима, као што су разне табеле, схеме и историјске карте. У посебну групу спадају филмови који се могу употребити парцијално, на делу часа или током целог часа.

\footnotetext{
2 Ученици могу сами на часовима додатне наставе правити имитације глинених таблица из Египта, капителе грчких стубова, макете манастира... што све може користити као пример каснијим генерацијама.

${ }^{3}$ Нпр. једна од битнијих догађајних слика која нам пружа значајне информације о Наполеону је она о његовом крунисању, аутора Жак Луј Давида.
} 
На основу ове поделе видимо да ликовног материјала за обраду било које наставне јединице има пуно, међутим није сваки једнако прикладан узрасту, структури одељења можда чак и сензибилитету наставника. Стога је неопходно извршити правилну селекцију материјала који се намерава користити и при одабиру поставити следећу хијерархију избора: „-важна дела ликовне културе, занимљива дела ликовне културе, технички беспрекорна (добра) дела ликовне културе, у ограниченом броју, не много него добро (non multa sed multum) демонстрирајући ликовни материјал, поткрепљује се наставно излагање, а максима, не много него добро, односи се на кључне садржаје, не на епизодне, јер развијају пажњу ученика" (Лазић 2008: 65).

Иако је наглашена предност унутрашње очигледности која је носилац предавања, што се мора поштовати, из приложеног се види да и спољашња има извесног значаја у стицању потпуног разумевања. Она пре свега подстиче два фактора који играју значајну улогу у савладавању наставног процеса наративних предмета, а то су мотивација која олакшава учење и емпатија која индиректно утиче на мотивацију и омогућава боље разумевање историје у ширем контексту.

\section{3. ФОТОГРАФИЈА У ИЗВОЪЕЊУ НАСТАВНЕ ЈЕДИНИЦЕ О ХОЛОКАУСТУ}

Фотографије спадају у ликовни материјал документарног карактера, кога чине још и фотокопије писаних историјских извора као и насловне стране књига, различитих рукописа и штампе. ${ }^{4}$ Значај фотографије, као што је речено у претходном поглављу, је у томе што она нуди аутентичност уколико је настала у периоду који се проучава ${ }^{5}$, али и репродукцију уколико је настала у каснијем времену у односу на објекат, личност, споменик који бележи. Таква фотографија може да замени екскурзију или посету неком историјском споменику уколико је реализација неизводљива а ученици неће

\footnotetext{
${ }^{4}$ О овоме детаљније видети Перовић 1995: 98.

${ }^{5}$ У том случају информисати ученике о кратком историјату фотографије, да је званично прва објављена у Паризу 19. августа 1839. године од стране француске академије наука. Први облик фотографије била је тзв. дагеротипија (механичко сликање) која је назив добила по иноватору Лују Дагеру. Прву фотографију у Србији је начинио Анастас Јовановић који је најплоднији стваралачки опус створио у току владавине кнеза Михаила Обреновића. Његова прва Свеска споменика сербских је објављена 6. августа 1850. године.
} 
бити ускраћени тог детаља. Пожељно је да за неке часове ученици (нпр. чланови фотосекције) и сами направе неколико фотографија које ће се користити на часу. У том случају и сами постају актери припреме часа чиме се остварује више циљева: подстицај унутрашње мотивације, превазилажење сумње у историјску истину која је честа међу ученицима и сам осећај доприноса колективу где посебно до изражаја могу доћи ученици који постижу слабији успех на часовима историје.

На тај начин боље упознају посао историчара и „схватају чему служи тражење, прикупљање и проучавање трагова прошлости (историјских извора), уочавају колико је сложено поставити критеријуме за важно и неважно у прошлости (најпре личној, а потом и прошлости заједница којима припадају), уочавају значај познавања историје за разумевање садашњости и сналажење у њој” (Шимуновић-Бешлин 2001: 83). Уколико се определимо за коришћење ове врсте ликовног материјала при извођењу неке наставне јединице, конкретно Последице рата - холокауст, геноцид, страдања у pamy из уџбеника за четврти разред гимназије општег и друштвено језичког смера, неопходно је придржавати се систематичности како би час био што прегледнији. Наиме, када се уради историјски осврт на фотографију потребно је, пре него што се види њен значај при обради теме холокауста, размотрити које нам она све предности и мане нуди као историјски извор и тиме развити критички став ученика, те их оспособити за правилну селекцију извора (материјалних или писаних) у случају проучавања неке тематике. Позитивне стране су:

1) чињенице које се поклапају са досадашњим сазнањима те принципом очигледности ученици виде оно што су чули или прочитали.

2) детаљи који могу употпунити слику социјалне, културне, емотивне структуре неке личности или времена уопште.

Негативне би могле бити:

1) могућност фотомонтаже - искривљивање стварности те у том случају уколико ученици немају довољно предзнања могу погрешно усвојити извесне чињенице.

2) разочарања - када ученик очекује идеализовани сегмент прошлости а добије нешто сасвим друго.

Наглашавањем ових позитивних и негативних страна указује се само на опрез али не треба створити одбојност ученика према коришћењу материјалних историјских извора. Методичари сматрају чак да „ликовни 
материјал документарног карактера се може по значају упоредити са писаним историјским документом који се користи у настави историје" (Перовић 1995: 98). Када су приказане опште фотографије ради разумевања њиховог контекста у настави историје прелази се на тематске, које се директно односе на наставну јединицу. Те фотографије наставник мора пажљиво одабрати; пожељно је да избор буде што већи, а при одабиру мора водити рачуна о неким методичким принципима:

1) фотографија мора бити конкретна, да ученик и ако не зна њену позадину може извести елементарне закључке.

2) мора бити технички прецизна, јасна да не смета у посматрању.

3) не сме бити узнемирујућа, те приказивати стварне призоре из рата које неки ученици не могу да посматрају са одређеном дистанцом...

По могућству за потребе наставе би било пожељно користити поред оних доступних и неке необјављене фотографије, али пре њихове употребе неопходно је извршити идентификацију на основу физичких карактеристика кроз три корака: 1) Када је настала фотографија 2) Где је настала 3) Ко је њен аутор. Разлози због којих нису до одређеног тренутка објављене могу бити вишеструки: „Јавност о снимљеном догађају није ни требало да буде обавештена или бар не на такав начин, фотографија може да буде необјављена и ако не задовољава захтеве објективности и информативности" (Ристић 1991: 126). Потребно је водити рачуна и о томе са ког места се фотографије узимају. Иако је данас најједноставније преко интернета доћи до свих жељених података и материјала, ипак не можемо све преузети са тог места јер је свакако пожељан фактор изненађења, те је вероватноћа да су поједини ученици те фотографије видели на бројним сајтовима сасвим извесна. Стога је препоручљиво консултовати архив, музеј, галерије и библиотеке у којима се могу набавити фотокопије неких раритетних примера. Јасно је да је неопходна висока припремљеност наставника за сваки час а посебно онај у коме се користи више облика и метода. То подразумева и перманентну едукацију образовног кадра не само стручну $^{6}$ већ и методичку ${ }^{7}$ и педагошку ${ }^{8}$. О условима успешности

\footnotetext{
${ }^{6}$ У овом случају историјску.

${ }^{7}$ Структура часа, циљеви и задаци.

${ }^{8}$ Она подразумева поштовање индивидуалности те прилагођавање одељењима у којима не може бити заступљен исти критеријум и постојати једнака очекивања јер су састави другачији.
} 
наставника нагласила је и професорка Кољанин: „Наставник историје мора да се усавршава у свим својим улогама: наставничкој (предавач, организатор наставе, партнер у педагошкој комуникацији, стручњак за своју област), мотивационој, процењивачкој, дијагностичкој, у улози регулатора у социјалној групи и у афективној интеракцији" (Кољанин 2001: 70).

\section{1. Селекција наставних облика и метода}

Данас су у предавачком систему заступљена три облика рада: фронтални, групни и индивидуални. Приликом обраде споменуте наставне јединице покушаћемо да укажемо на правилан избор коришћења фотографије као ликовног материјала у настави историје. Први облик рада, познат и под називом колективни или разредни је најпримењивији у извођењу наставе код хуманистичких наука јер свакако доминира жива реч где се ученицима нуди обрађена информација, прегледност градива и уобличена слика о одређеној тематици. Наставник ради истовремено са целим одељењем ${ }^{9}$, због чега се овај облик сматра економичним али и најсигурнијим за извођење унапред постављених циљева јер највише зависи од квалитета припремљености наставника. Ипак, искључивом употребом фронталног приступа отворена је и могућност пасивизације ученика.

У извођењу наставне јединице Последице рата - холокауст, геноцид, страдања у рату, у оквиру које је планирана употреба фотографије, фронтални облик има секундарни карактер, активан је на почетку часа када се ученици уводе у лекцију, приликом објашњавања кључних појмова ${ }^{10}$ и приликом давања упутстава за обављање задатака. Групни облик мора на овом часу доминирати, дакле подела на три до пет чланова водећи рачуна о формирању групе по критеријуму успеха. При

9 Води рачуна о индивидуалним могућностима ученика, дакле увек треба да има припремљене информације напреднијег нивоа намењене заинтересованим ученицима, али и основна питања до чијих се одговора може доћи коришћењем свеске, те тиме у наставни процес укључује све ученике одељења у рад.

10 У настави историје значајну улогу мора имати дефинисање стручне терминологије због тога што се разумевање речи не постиже извлачењем из контекста јер то врло често бива погрешно протумачено, а и због богаћења личног речника те се провера разумевања историјске терминологије препоручује усмено или писмено. 
обради ове наставне јединице доминирају појмови - фашизам ${ }^{11}$, геноцид и холокауст о броју жртава из Другог светског рата (подаци се налазе у табели уџбеника Историја за трећи разред гимназије природно математичког смера и четврти разред општег и друштвено језичког смера, Завод за уџбенике, Београд 2016, стр. 177). Ученици добијају тачно утврђене задатке везане за идентификацију и анализу историјског контекста које решавају заједно, а потом вођа групе интерпретира резултате одељењу након тачно утврђеног времена.

„Овакав облик рада ослобађа ученике страха у комуникацији наставник-ученик, своди обраду методске јединице на минимум вербализма, развија њихову иницијативу и ангажованост, навикава ученике на међусобну сарадњу и помоћ...Омогућава успешну реализацију све три фазе рада: припрему, самостални рад и свођење резултата" (Лазић 2008: 28). Трећи облик, индивидуални, на овом часу нема значајну улогу сем ако је у одељењу мали број ученика па се сваком ученику може посебно дати по неколико фотографија. У оквиру ових облика ученици добијају више задатака и тиме постају мисаоно ангажованији. У избору наставних облика не би требало прибегавати искључивости већ разноврсности. Са тим у вези препоручује се и довођење гостију (универзитетских професора или сведока неког историјског момента), едукативне игре у виду квизова... ${ }^{12}$

Избор метода је вишеструк. Општа подела у оквиру наставе историје је на вербално-текстуалне и илустративно-демонстративне о којима је већ било речи. ${ }^{13}$ У складу са темом рада свакако је најподеснија монолошка, која би доминирала на почетку часа и дијалошка (метода разговора), која би била носилац часа јер би свака група требала након свог излагања да отвори дискусију о понуђеним фотографијама и на тај начин активира остале ученике који се могу укључити са својим импресијама, примерима, знањима

${ }^{11}$ Појава фашизма је уско повезана са идеологијом националсоцијализма у Немачкој што је Волфганг Шидер објаснио на следећи начин: „Претварање фашистичке у тоталитарну диктатуру са фашистичким обележјима била је претпоставка за избијање Другог светског рата и организовано уништавање великог броја Јевреја у Европи од стране националсоцијализма, за које италијански фашизам свакако није био пример, али у којем је и он, као и остали колаборационистички режими, индиректно учествовао од 1943. Тиме је немачки фашизам знатно одступио од свог историјског узора у Италији, али се његов настанак ипак без тог узора не може објаснити" (Шидер 2010: 212).

${ }^{12}$ О овоме детаљније видети Требјешанин (2009: 73-74).

${ }^{13}$ О овоме детаљније видети Перовић (1995: 50). 
и тако обухвати читаву наставну тему о Другом светском рату. Овим часом је могуће резимирати сва знања у оквиру ове теме из домена политичке и друштвене историје. Када ученици одаберу материјал са којим ће радити треба им дати детаљна упутства која ће добити и у писаној форми. Добиће опште информације о историји фотографије у уводном делу часа као и о њеним предностима и манама за историчаре. На платну ће моћи да виде неке примере из којих се најбоље илуструју ове особености. Посебна пажња ће бити посвећена модним детаљима који се на неким фотографијама из двадесетих година двадесетог века могу најбоље уочити. Најбољи начин да се ученици ангажују је подела у групе приликом чега би свакој групи могли поделити по две фотографије о којима ће ученици решавати два задатка (за сваку фотографију посебно). У првом задатку би ученици формирали своју верзију приче на основу које ће се потрудити да слушаоцима дају основне (импровизоване) податке у оквиру кога ће претпоставити неколико ствари: где се радња одвија, у ком периоду, ко су актери, евентуалне податке о појединцима и дати свој суд о аутентичности и мотивима настанка фотографије. У другом задатку би ученици забележили која осећања изазивају приказани догађаји. Када истекне време предвиђено за консултације вођа групе ће изаћи испред табле са својим фотографијама и залепити стикере са наведеним емоцијама када ће и остали ученици имати право да дају своје коментаре, да допуне, критикују. Када изнесу тезе са коментарима на одређене личности, догађаје или призоре тада ће такође остатак одељења моћи да учествује са сазнањима о локацији ${ }^{14}$, узроцима, последицама али и сведочењима чланова њихових породица које су на директан или индиректан начин били сведоци оваквих дешавања. Неке од фотографија које је на овом часу могуће користити су оне приказане у раду, означене бројевима о којима ће на крају изведеног часа професор рећи нешто детаљније. Нпр. фотографија број 1 приказује Ирму Грес, осамнаестогодишњу чуварку из Аушвица која је у складу са својим понашањем имала надимак хијена. Посебно је била позната по сексуалним склоностима према затвореницима и садистичком уживању. После рата је осуђена на смрт вешањем. Фотографија број 2 приказује групу Рома у

\footnotetext{
14 У том делу часа потребно је указати ученицима на карту са 178. стране (Уџбеник из историје за четврту годину душтвено језичког смера, издање Завода за уџбенике) која приказује концентрационе логоре на подручју Европе са бројем јеврејских жртава у свакој држави.
} 
једном од концетрационих логора у периоду између 1941-1945. године. Ова фотографија се налази на изложби Роми у холокаусту у јеврејској заједници Бет Исраел у Загребу. Фотографија број 3 приказује сегмент рације из 1942. године у Новом Саду на којој мађарски војници врше ликвидацију локалног становништва у Милетићевој улици непосредно пред одношење жртава под залеђени Дунав. Фотографија број 4 приказује сцену мучења логораша из логора Бањица, која је направљена 1942. године. Неизоставна је координација наставника између групе и одељења, он подстиче својим сугестијама на коришћење стеченог знања и продубљивање одређених питања. Својим учешћем наставник даје простора и тзв. хеуристичком методу: „Постављањем питања указује на проблеме, формулише противуречности, изазива полемичке ситуације и каналише дискусију” (Перовић 1995: 49). Да би дискусија била успешна а комуникација са ученицима остварила постављене циљеве мора се поштовати неколико дидактичко- методичких правила: 1) Стваралачке паузе које подразумевају поштовање кратког застоја за концентрацију након постављених питања на релацији наставник-ученик или ученик-ученик. 2) Поштовање странпутица у размишљању - када и наставник и остали ученици имају толерантан став према погрешним одговорима и када се од наставника очекује да наведе ученика на тачан одговор. 3) Одлагање решавања задатака - када се решење појединих проблемских ситуација суптилно пролонгира како би се омогућило и споријим ученицима да дају одговоре. ${ }^{15}$

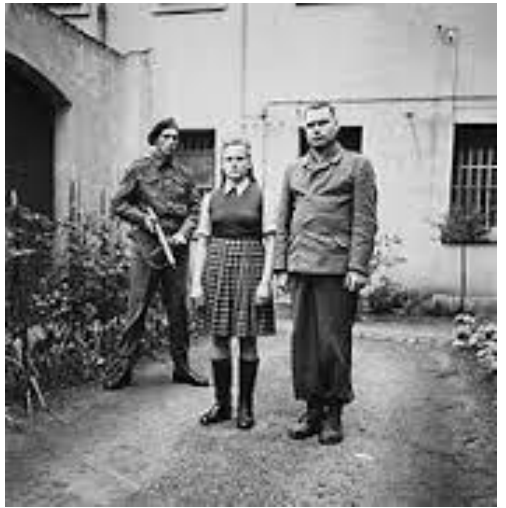

Фотографиja 1.

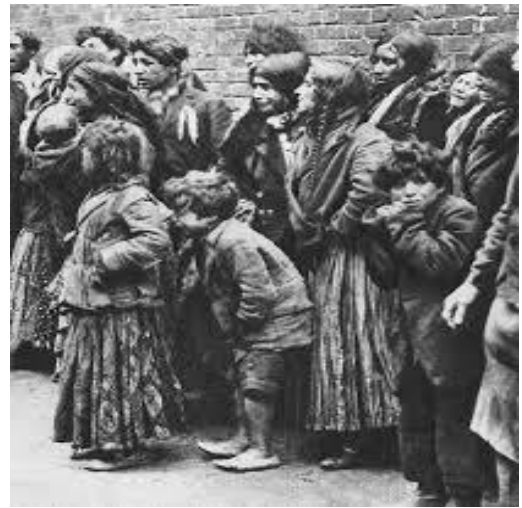

Фотографија 2.

${ }^{15}$ Детаљније видети Маринковић 1995: 38-39. 


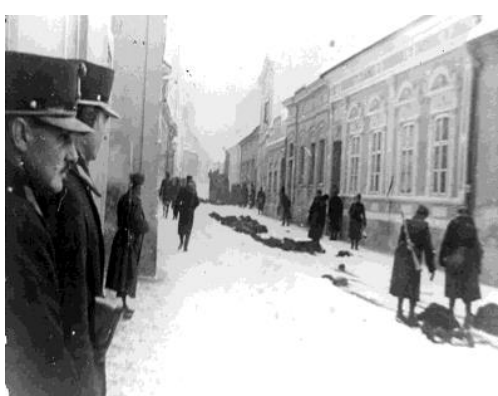

Фотографиja 3.

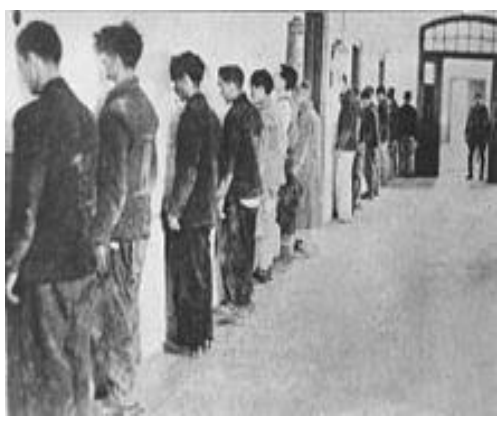

Фотографија 4.

Фотографија 1: Ирма Грес, осамнаестогодишња чуварка у логору Аушвич

Фотографија 2: Група Рома у кониентрационом логору

Фотографија 3: Раиија у Новом Саду 1942. године

Фотографија 3: Логораши из Бањище

\section{4. РЕЗУЛТАТИ АНКЕТЕ О УПОТРЕБИ ФОТОГРАФИЈЕ У НАСТАВИ ИСТОРИЈЕ}

Спроведеном анкетом обрађена су 93 узорка ${ }^{16}$ из којих су добијени приказани статистички подаци међу којима нам неки индукују евентуалне смернице у будућем извођењу наставе у оквиру споменуте наставне јединице. Анализирајући добијене вредности увиђамо да ученици често уочавају све детаље фотографије, споредне елементе као што су архитектура, мода... те се препоручују заједничке анализе у процесу визуелизације и континуиране дигресије на различите теме у току часа. Изражена кумулативна вредност у корист четвртог питања указује нам да неке фотографије подстичу заинтересованост за наставну јединицу и чак потребу за додатним сазнањима, из чега следи да при обради теже или потенцијално мање интересантне лекције треба форсирати селектоване фотографије у складу са темом. Резултат шестог питања указује на неопходну употребу разноврсних наставних облика, а пре свега групног рада (у виду радионица), као и учења путем открића где се максимално

${ }^{16}$ Анкета је спроведена међу ученицима четврте године филолошке гимназије у Сремским

Карловцима. 
активира ангажованост ученика те поспешује динамика часа. Чак $83,9 \%$ је одговорило да се слаже са активношћу повезивања фотографија са понуђеним историјским догађајима на часовима понављања (колаж техника), 16,1\% се делимично слаже, док из групе који се не слажу није био ниједан ученик. У осмом питању висок проценат испитаника прихвата коришћење узнемирујућих фотографија, те новије генерације показују отвореност ка динамици и интензивнијим емоцијама што може бити показатељ потребе за благим ревидирањем структуре уџбеничких фотографија. Али се мора обратити пажња и на део ученика који је против што наговештава обазрив избор наставног материјала. И на крају је приказана објективна констатација ученика у хијерархији наставно образовног материјала, редоследа текст - видео запис - фотографија у вези са којом и предавачи треба да поступају водећи рачуна истовремено о методичким компетенцијама и потребама ученика.

Приказане табеле дају детаљно обрађене резултате спроведене анкете а подељене су у зависности од типа питања ради боље прегледности.

\begin{tabular}{|c|l|c|c|c|c|}
\hline $\begin{array}{l}\text { Редни бр. } \\
\text { питања }\end{array}$ & $\begin{array}{l}\text { Питање } \\
\text { Уопшт } \\
\text { се не } \\
\text { слажем }\end{array}$ & $\begin{array}{l}\text { Делимично } \\
\text { се слажем }\end{array}$ & $\begin{array}{l}\text { Потпуно } \\
\text { се } \\
\text { слажем }\end{array}$ & $\begin{array}{l}\text { Стандардна } \\
\text { девијација }\end{array}$ \\
\hline 1. & $\begin{array}{l}\text { Бољи ефекат на } \\
\text { посматрача остављају } \\
\text { портретне фотографије } \\
\text { од осталих. }\end{array}$ & $\mathbf{2 5 , 8 \%}$ & $\mathbf{5 1 , 6 \%}$ & $\mathbf{2 2 , 6 \%}$ & $\mathbf{0 , 6 9 8 6 3}$ \\
\hline 2. & $\begin{array}{l}\text { Посматрајући } \\
\text { фотографије у } \\
\text { ушбенику често поред } \\
\text { главне теме сагледавам } \\
\text { и споредне. }\end{array}$ & $\mathbf{1 8 , 3 \%}$ & $\mathbf{3 9 , 8 \%}$ & $\mathbf{4 1 , 9 \%}$ & $\mathbf{0 , 7 4 3 0 5}$ \\
\hline 3. & $\begin{array}{l}\text { Фотографије су бољи } \\
\text { историјски извор од } \\
\text { табела или графикона } \\
\text { са статистичким } \\
\text { подацима. }\end{array}$ & $\mathbf{7 , 5 \%}$ & $\mathbf{3 6 , 6 \%}$ & $\mathbf{5 5 , 9 \%}$ & $\mathbf{0 , 6 3 6 1 0}$ \\
\hline 4. & $\begin{array}{l}\text { Неке фотографије } \\
\text { подстичу моју } \\
\text { заинтересованост за } \\
\text { наставну јединицу или }\end{array}$ & $\mathbf{5 , 4 \%}$ & $\mathbf{3 1 , 2 \%}$ & $\mathbf{6 2 , 5 \%}$ & $\mathbf{0 , 5 9 7 3 1}$ \\
\hline
\end{tabular}




\begin{tabular}{|c|l|c|c|c|c|}
\hline & додатна сазнања. & & & & \\
\hline 5. & $\begin{array}{l}\text { Корисно би било када } \\
\text { би ученици сами } \\
\text { правили неке } \\
\text { фотографије за потребе } \\
\text { часа (спомен плоче, } \\
\text { споменике, објекте...). }\end{array}$ & $\mathbf{2 0 , 4 \%}$ & $\mathbf{4 9 , 5 \%}$ & $\mathbf{3 0 , 1 \%}$ & $\mathbf{0 , 7 0 8 1 0}$ \\
\hline 6. & $\begin{array}{l}\text { Сматрам да би било } \\
\text { корисно на часу } \\
\text { понављања повезивати } \\
\text { фотографије са } \\
\text { понуђеним историјским } \\
\text { догађајем. }\end{array}$ & $\mathbf{1 6 , 1 \%}$ & $\mathbf{8 3 , 9 \%}$ & $\mathbf{0 , 3 6 9 7 9}$ \\
\hline
\end{tabular}

Табела 1. Анализа уцбеничке фотографије

\begin{tabular}{|c|l|c|c|c|}
\hline $\begin{array}{c}\text { Редни бр. } \\
\text { питања }\end{array}$ & \multicolumn{1}{|c|}{ Питање } & не & да & $\begin{array}{c}\text { Стандардна } \\
\text { девијација }\end{array}$ \\
\hline 7. & $\begin{array}{l}\text { Да ли је могућа потпуна } \\
\text { емпатија коришћењем само } \\
\text { писаног историјског извора? }\end{array}$ & $\mathbf{6 3 , 4 \%}$ & $\mathbf{3 6 , 6 \%}$ & $\mathbf{0 , 4 8 4 2 1}$ \\
\hline 8. & $\begin{array}{l}\text { Прихватам употребу } \\
\text { узнемирујући фотографија. }\end{array}$ & $\mathbf{2 3 , 7 \%}$ & $\mathbf{7 6 , 3 \%}$ & $\mathbf{0 , 4 2 7 2 7}$ \\
\hline
\end{tabular}

Табела 2. Улога емоција у употреби фотографија

\begin{tabular}{|c|l|c|c|c|}
\hline $\begin{array}{l}\text { Редни бр. } \\
\text { питања }\end{array}$ & \multicolumn{1}{|c|}{ Питање } & $\begin{array}{l}\text { видео } \\
\text { запис }\end{array}$ & фотографија & текст \\
\hline 9. & $\begin{array}{l}\text { Поређај понуђене изворе } \\
\text { по степену важности } \\
\text { бројевима од 1 до 3. }\end{array}$ & $\mathbf{3 8 , 7 \%}$ & $\mathbf{8 , 6 \%}$ & $\mathbf{5 2 , 7 \%}$ \\
\hline
\end{tabular}

Табела 3. Фотографија као историјски извор

\section{5. ЗАКЉУЧАК}

У настави историје постоје различити начини извођења предавања у којима је, за који год да се определимо, најважније постићи мотивацију 
ученика за учењем, јер без обзира колико успешно преносили знање све зависи од њиховог самосталног и редовног рада. Рад је у историјској науци условљен читањем које је основни предуслов за савладавање градива и стицање широког образовања. Извођење наставног процеса је сложен поступак који подразумева велику стручну компетенцију наставника али и његове методичко-дидактичке вештине у које спадају организација часа, степен прилагођености одељењу, концизност у постављању задатака ученицима како би се реализовали захтеви. Историја је такав предмет у коме примарну улогу има реч наставника и његова интерпретација одређеног градива (од које се очекују нијансиране дигресије на тему везане за садашњост), али фронтални приступ никада не може бити једини који се примењује у току часа јер тада ученицима нуди готова решења, дистанцира их од логичког поимања и доводи до пасивног положаја. Изгледи за успешност исхода часа су извеснији уколико се комбинује више облика и више наставних метода при обради једне наставне јединице. Иако је неизоставна монолошко-дијалошка метода при обради великог броја наставних јединица, у историји је препоручљиво и коришћење илустративно-демонстративне методе. Уколико се определимо за фотографију као наставно средство морамо водити рачуна о изградњи критичког става ученика и подизања њихове свести на ниво самопроцене њене вредности и аутентичности али и показати предности у коришћењу материјалних историјских извора. Пратећи развој фотографије од њеног настанка до данас ученици могу видети предности у бележењу важних историјских момената те подстаћи себе на размишљање шта из данашњег угла губимо непостојањем механичког сликања неког призора из свакодневног живота средњег века или још дубље у прошлости. Принцип очигледности је значајан у настави историје и стога је коришћење сваког предмета и вануџбеничког материјала добродошло. Тиме се намеће потреба за корелацијом историје са свим осталим предметима. Оно што отвара могућност реализације успешног часа јесте размена идеја и искустава наставника унутар школе и ван ње што се постиже извођењем угледних часова. 


\section{ЛИТЕРАТУРА}

Ђурић Ђ, Павловић М. (2012). ИСТОРИЈА за трећи разред гимназије природно-математичког смера и четврти разред гимназије општег $и$ друштвено-језичког смера. Београд: Завод за уџбенике.

Кољанин, Д. (2001). „Наставник историје и уџбеник”. Настава историје 14: 69-72.

Лазић, М. (2008). Методички приручник из историје. Београд: Друштво историчара Србије Стојан Новаковић - Институт за савремену историју.

Маринковић, С. (1995). Методика креативне наставе српског језика и књижевности. Београд: Креативни центар.

Перовић, М. (1995). Методика наставе историје. Београд: Завод за уџбенике и наставна средства.

Ристић, Љ. (1991). „Фотографија као историјски извор”. Зборник Матице српске за uсторију 43: 119-128.

Секулић, Ж. (1998). „Настава историје и музеологија”. Настава историје 7: 180181.

Требјешанин, Б. (2009). Мотиваиија за учење: теорија, приниипи, примена. Београд: Учитељски факултет.

Шидер, В. (2010). „Фашизам“. Историја, лексикон појмова. Београд: Clio: 191-212. Шимуновић-Бешлин, Б. (2001). „О циљевима наставе историје”. Настава историје 14: 82-88.

Nikola Krčmar

\section{THE USE OF PHOTOGRAPHS IN HISTORY LESSON ON THE TOPIC OF HOLOCAUST}

\section{Summary}

The paper discusses the most optimal choices of forms and teaching methods that can be used in a lesson on Holocaust. The emphasis is on scientific, methodological, pedagogical and psychological competencies of the teacher as the basic prerequisites for proper realization of a history lesson. The paper presents a way of using historical art material as a visual aid in teaching history with other teaching methods while making sure that they complement each other properly. When selecting photographs to be included in history lessons on Holocaust, there are several principles to be met: the photograph must be specific, so that the student can deduce elementary things about it, even in he/she does not know the background; the photograph must be technically precise and clear; the photograph must not portray disturbing images that students may find upsetting.

Photograph as a documentary material can be used not only in history lessons, but also in the structure of other narrative subjects where notable space is given to the selection of materials. An important part of teaching that can be observed here is the question of 
motivation, which should be improved by combining different teaching forms. The paper includes the most important methodological principles, which the teacher must adhere to, and an annex containing lesson plan on the subject of Consequences of the war Holocaust, genocide, and casualties. The effects of the presented lesson were investigated with a survey that included 93 high school students, who generally assessed the visual teaching material in a positive way and expressed a belief that photographs help the construction of empathy among students and that they should definitely be included in the teaching process.

Keywords: photograph, Holocaust, history teaching, teaching methods in history, World War II.

Primljeno: 17.5.2017.

Prihvaćeno: 27.11.2017. 